\title{
Peningkatan Nilai Usaha Kopi Pada Panti Karya Salib Putih Salatiga
}

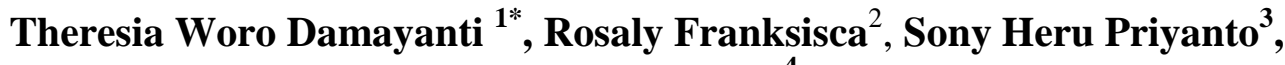 \\ Djoko Murdoko \\ ${ }^{1,2,3,4}$ Program Studi Akuntansi, Universitas Kristen Satya Wacana Salatiga Indonesia \\ J1. Diponegoro 52-60 Salatiga \\ *e-mail : theresia.damayanti@uksw.edu
}

\begin{abstract}
ABSTRAK
Panti Karya Salib Putih merupakan lembaga yang menampung warga usia produktif (25-60) yang tidak mampu bekerja di organisasi atau lembaga yang kompetitif. Untuk memenuhi kebutuhan mereka, pengelola mengusahakan kopi, mulai dari produksi sampai pennjualan bubuk kopinya. Masalahnya adalah produktivitas kopi masih rendah, pengolahan kurang maksimal sehingga hasil dari produk kopi juga tidak maksimal. Kegiatan pengabdian masyarakat ini bertujuan untuk meningkatkan kapasitas hasil produksi kopi, meningkatkan manajemen pengolahan kopi menjadi produk kopi dan meningkatkan jumlah hasil produk kopi. Untuk mencapai tujuan peningkatan kapasitas hasil produksi kopi, dilakukan dengan mereview kondisi eksisteng dari tanah. Berdasarkan hasil analisis tanah dari pengujian laboratorium, maka dilakukan pemilihan teknik pemupukan yang tepat. Selain memperbaiki kualitas tanah, juga dilakukan perbaikan kualitas dan kuantitas tanaman kopi supaya mencapai hasil yang maksimal dengan melakukan peremajaan tanaman kopi. Untuk meningkatkan manajemen pengolahan kopi menjadi produk kopi dan meningkatkan jumlah hasil produk kopi, dilakukan dengan pengadaan alat roasting yang baik dan pemasaran hasil produk kopi yang baik pula.
\end{abstract}

Kata kunci: nilai usaha, kopi, produk kopi, panti karya 


\begin{abstract}
Panti Karya Salib Putih is an institution that accommodates people of productive age (25-60) who are unable to work in competitive organizations or institutions. To meet their needs, the administrator of the institution engage in coffee, from production to the sale of ground coffee. The problem arises are coffee productivity is still low, processing is not optimal so the results of coffee products are also not optimal. This community service is to increase the capacity of coffee production, improve the management of coffee processing, from beans to coffee products, and increase the amount of coffee productions. A review on existing condition of the soil is being conducted to achieve the goal of increasing the capacity of coffee production. Based on the results of soil analysis from laboratory testing, the selection of appropriate fertilization techniques is carried out. In addition to improving soil quality, improvements are also made to the quality and quantity of coffee plants in order to achieve maximum results by rejuvenating coffee plants. To improve the management of coffee bean processing into ground coffee and to increase the amount of coffee, a good roasting tool is procured and supported with good and on target marketing of the product.
\end{abstract}

Keywords: business value, coffee, ground coffee, panti karya

\title{
PENDAHULUAN
}

Masalah sosial gelandangan dan pengemis (Gepeng) merupakan fenomena sosial yang tidak bisa dihindari keberadaannya dalam kehidupan masyarakat, terutama yang berada di daerah perkotaan. Salah satu yang mempengaruhi perkembangan masalah ini adalah kemiskinan. Masalah kemiskinan di Indonesia berdampak negatif terhadap meningkatnya arus urbanisasi dari daerah pedesaan ke kota-kota besar, sehingga terjadi kepadatan penduduk dan daerah-daerah kumuh yang menjadi pemukiman para urban tersebut. Lapangan pekerjaan yang terbatas, serta minimnya pengetahuan dan ketrampilan menyebabkan banyak yang mencari nafkah untuk mempertahankan hidup dengan terpaksa menjadi gelandangan dan pengemis (Ari, 2014).

Provinsi Jawa Tengah memiliki tantangan berkaitan dengan masalah sosial. Penyandang masalah sosial di Provinsi Jawa Tengah mencapai 6.090.369 jiwa (Prasetyo, 2012). Jumlah tersebut meupakan $18 \%$ dari jumlah penduduk di Jawa Tengah, dengan proporsi terbesar adalah pengemis yaitu sejumlah 5.146.267 jiwa atau 15.34\%. Selain pengemis, pengangguran juga merupakan masalah sosial yang perlu ditangani di Provinsi Jawa Tengah. Menurut data dari Biro Pusat Statistik (2019), pengangguran di Jawa Tengah selama kurun waktu 3 tahun terakhir mencapai lebih dari $4 \%$ dari jumlah penduduk. 


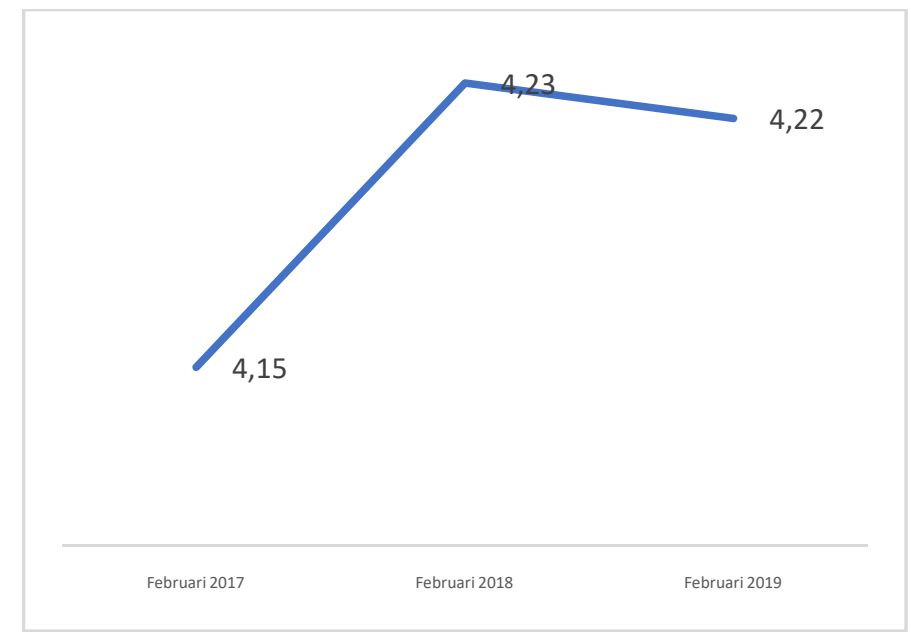

Gambar 1. Trend Pengangguran di Jawa Tengah

Salah satu langkah yang dilakukan baik oleh pemerintah maupun privat adalah dengan melatih para pengangguran untuk dapat berkaya di masyarakat, salah satunya melalui Panti Sosial Bina Karya. Panti sosial bina karya adalah Panti sosial yang mempunyai tugas memberikan pelayanan dan rehabilitasi sosial bagi para gelandangan, pengemis dan orang terlantar agar mampu mandiri dan berperan aktif dalam kehidupan bermasyarakat. Menurut Peraturan Menteri Sosial Republik Indonesia No 106/HUK/2009 Tentang Organisasi dan Tata Kerja Panti Sosial di Lingkungan Departemen Sosial, Panti Sosial Bina Karya mempunyai tugas memberikan bimbingan, pelayanan dan rehabilitasi sosial yang bersifat kuratif, rehabilitatif, promotif dalam bentuk bimbingan pengetahuan dasar pendidikan, fisik, mental, sosial, pelatihan keterampilan, resosialisasi bimbingan lanjut bagi para gelandangan, pengemis dan orang terlantar agar mampu mandiri dan berperan aktif dalam kehidupan bermasyarakat serta pengkajian dan penyiapan standar pelayanan dan rujukan.

Perguruan tinggi memiliki tanggung jawab utama, yakni Tri Dharma Perguruan Tinggi. Pengabdian masyarakat merupakan salah satu pilar Tri Dharma Perguruan Tinggi. Perguruan Tinggi harus mempunyai visi untuk mengabdi kepada kepentingan bangsa dan kemanusiaan dengan dijiwai oleh nilai-nilai budaya bangsa yang berdasarkan Pancasila (Marwasta, 2017). Pengabdian masyarakat yang dilaksanakan oleh perguruan tinggi harus berbentuk kolaborasi antara berbagai pihak untuk berkarya bersama demi kemajuan Indonesia. Dukungan semua pihak sangat diperlukan, termasuk dukungan berupa kegiatan pengabdian kepada masyarakat yang dilakukan oleh perguruan tinggi. Hal tersebut sesuai dengan strategi sinergi kegiatan dengan model pentahelix berikut ini. 


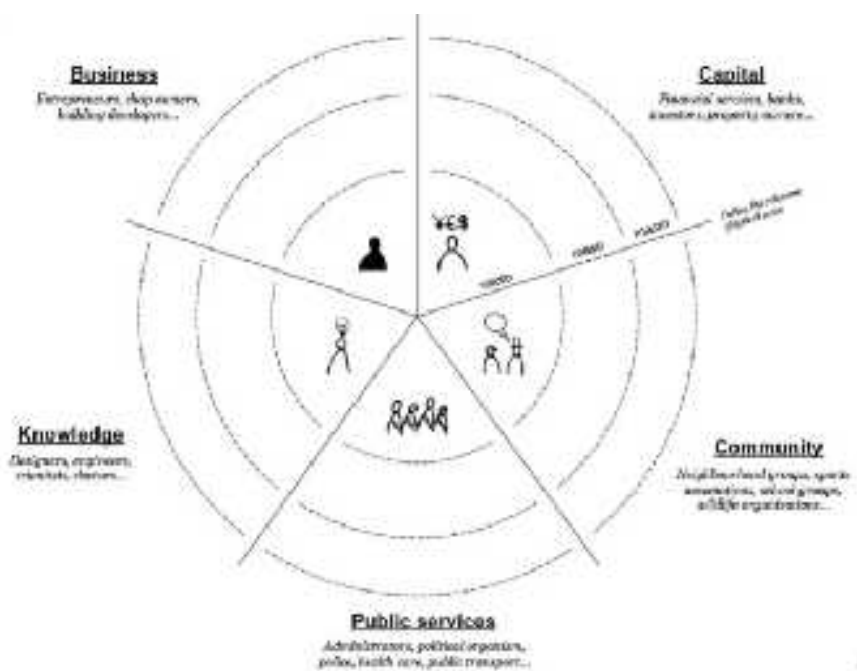

Gambar 2. Pentahelix

Panti Karya Salib Putih merupakan lembaga yang menampung warga usia produktif (25-60) yang tidak mampu bekerja di organisasi atau lembaga yang kompetitif. Misalnya warga yang terganggu jiwanya namun dalam usia produktif, panti ini mau menerima dengan diberi penampungan sederhana, pemberian uang lauk pauk sederhana dengan pembimbingan untuk bekerja di kebun Kopi. Ada 12 Kepala Keluarga yang tinggal menjadi kalayan bersama dengan keluarganya. Untuk memenuhi kebutuhan mereka, pengelola mengusahakan kopi, mulai dari produksi sampai pennjualan bubuk kopinya.

Selama ini Tim manajemen Panti, dibantu sekitar 12 kalayannya, memelihara kopi turun temurun, diproduksi, dipanen-ditebaskan, produksi $482.75 \mathrm{~kg}$ per ha, dengan lahan garapan 4 hektar. Setelah panen, dikeringkan dan digiling secara konvensional, kemudian dikemas dan dijual secara door to door. Tenaga kalayan sudah diatas 45 tahun dan tidak produktif seperti SDM lainnya. Usaha dijalankan secara sederhana dan manajemen pencatatan sederhana pula.

Masalahnya adalah produktivitas kopi masih rendah. Produktivitas merupakan perbandingan antara hasil produksi dengan input. Menurut Herjanto (2007), produktivitas adalah pencapaian atas pengaturan sumber daya dan pemanfaatannya untuk menghasilkan sesuatu yang optimal. Produktivitas dapat digunakan mencerminkan keberhasilan atas aktivitas yang dilakukan. Produktivitas di Panti Karya Salib Putih hanya $482 \mathrm{~kg} / \mathrm{ha}$, pengolahan kopi masih sederhana, tidak efisien dan produktif, manajemen usaha terbatas dan pemasaran masih mengandalkan pasar lokal dan sederhana. Rendahnya produktivitas kopi bubuk kopi tidak terlepas dari kondisi alat pengolahnya. Saat ini, pengelola menggunakan alat pinjaman dari PT. Rumekso Mekaring. Hanya saja alat tersebut kurang maksimal karena tidak ada pengatur suhunya. Akibatnya seringkali bubuk kopi hasilnya tidak memenuhi kualitas, kuantitas dan kontinuitas yang diharapkan. Pengelola berharap memiliki alat sendiri yang maksimal dalam mengolah produk kopinya sehingga mereka bisa meningkatkan hasil dan proses produksi bisa dilakukan setiap saat. 
Secara umum, pengabdian masyarakat ini bertujuan untuk meningkatkan nilai usaha dari tanaman dan produk kopi yang dikelola oleh Panti Karya Salib Putih. Untuk mewujudkan tujuan umum tersebut dirumuskan tujuan spesiik sebagai berikut (1) meningkatkan kapasitas hasil produksi kopi (2) meningkatkan manajemen pengolahan kopi menjadi produk kopi dan (3) meningkatkan jumlah hasil produk kopi

Kegiatan pengabdian masyarakat bermanfaat untuk membantu peningkatan nilai usaha kopi di panti Karya Salib Putih maka panti Karya ini dapat berjalan secara berkesinambungan yang bermuara pada (1) menjaga keberlangsungan dari panti Karya Salib Putih (2) memberikan pengetahuan kepada kalayan dalam pengelolaan usaha dan (3)membantu pemerintah dalam penanganan pengangguran

\section{METODE}

Secara umum ada empat solusi yang akan ditawarkan ke Mitra yaitu

1. Pemetaan potensi dan masalah mitra

2. Perancangan solusi berbasis masalah

3. Penyusunan detail engineering pelaksanaan program

4. Perbaikan budidaya tanaman kopi.

Untuk mencapai tujuan meningkatkan kapasitas hasil produksi kopi, metode pelaksanaannya adalah mereview kondisi tanaman eksisting. Hasilnya akan digunakan untuk memperbaiki kualitas tanaman, yang bisa dilakukan dengan beberapa langkah yaitu:

a) Peremajaan tanaman kopi.

Peremajaan tanaman kopi dilakukan melalui penggantian tanaman dengan bibit baru dengan tujuan meningkatkan hasil panen. Peremajaan perlu dilakukan sebab tanaman kopi yang sudah tua semakin tidak produktif lagi, karena rentan terkena serangan hama dan penyakit. Alhasil tingkat produktivitas kopi pun rendah sekali. Oleh sebab itu dilakukan dengan menghilangkan pohon kopi yang sudah tua dan menanam pohon kopi yang baru.

b) Memilih tanaman kopi unggulan yang telah terbukti memiliki tingkat produktivitas yang tinggi.

c) Pemberian pupuk yang tepat wajib dilakukan dalam budidaya tanaman termasuk tanaman kopi. Pupuk terbukti sebagai sumber nutrisi bagi tanaman untuk membantu pertumbuhan tanaman. Pemberian pupuk secara tepat baik dosis, waktu, maupun aplikasi akan memaksimalkan pertumbuhan tanaman.

d) Pemangkasan secara berkala yang dilakukan dengan memangkas bagian-bagian tanaman yang tidak berguna. Diantaranya adalah cabang yang sudah tua, ranting yang mengering, atau daun yang terlalu rimbun. Pemangkasan bermanfaat bagi peningkatan produktivitas tanaman kopi.

e) Tanaman supaya tumbuh maksimal bisa dirangsang menggunakan zat-zat tertentu dengan tujuan menghasilkan buah lebih cepat. Zat perangsang tersebut salah satunya adalah ZPT.

Sementara untuk mencapai tujuan meningkatkan manajemen pengolahan kopi menjadi produk kopi dan meningkatkan jumlah hasil produk kopi dilakukan melalui perbaikan/penggantian alat pengolah kopi. Terdapat empat metode yang dilakukan yaitu

a) Persiapan. Pada tahap ini, akan dilakukan persiapan pengadaan alat, termasuk tempat alatnya. Akan dicek sekali lagi mengenai kebutuhan dan spesifikasi serta kapasitas alatnya. 
b) Pengadaan alat. Alat akan dibeli seperti yang telah disepakati dengan mitra, dengan kapasitas $25 \mathrm{~kg}$, bahan stainless steel dan ada pengatur suhunya.

c) Coaching. Pada tahan ini akan ada coaching atau pembekalan mengenai penggunaan dan pemeliharaan alat tersebut agar supaya alat bisa dimanfaatkan secara maksimal

d) Pengolahan. Jika sudah siap semua, alat akan digunakan untuk mengolah biji kopi.

\section{HASIL DAN PEMBAHASAN}

Yayasan Salib Putih adalah yayasan sosial yang terletak di kota Salatiga. Yayasan Salib Putih didirikan saat meletusnya Gunung Kelud di Jawa Timur tahun 1901. Sekitar 300 jiwa yang berasal dari desa di sekitarnya mengungsi hingga sampai dan berkumpul di alun-alun kota Salatiga (sekarang menjadi lapangan Pancasila Salatiga). Merasa empati dengan kondisi pengungsi yang lemah, pasangan suami istri A Th J van Emmerick dan Alice Cleverly tergerak untuk memberikan pertolongan. Akhirnya mereka ditampung dan dirawat sementara di rumah keluarga van Emmerick di Salatiga.

Keluarga ini dibantu para pengungsi kemudian membuka lahan, mendirikan barakbarak penampungan yang dilakukan secara swadaya dan memulai menempatinya pada tanggal 14 Mei 1902. Inilah awal mula berdirinya Yayasan Salib Putih. Nama Salib Putih merupakan terjemahan dari nama perkumpulan yang didirikan keluarga van Emmerick yaitu Witte Kruis Kolonie (WKK). Van Emmerik memberi nama perkumpulan yang dibangunnya tersebut berdasarkan penemuan marmer putih berbentuk salib ketika membuka lahan.

Perkembangan selanjutnya, banyak hibah tanah untuk menampung para pengungsi dan korban. Selain itu, keluarga van Emmerick juga membeli tanah dari penduduk sekitar, sehingga tanah yang dimiliki Yayasan Salib Putih bertambah luas. Tanah ini kemudian dikelola untuk kebutuhan rutin serta dibangun berbagai sarana prasarana untuk pelayanan. Sampai tahun 1930, Yayasan Salib Putih ini merawat 1200 orang lebih.

Yayasan Salib putih beropersi berlandaskan ajaran bahwa sebagai sesama ciptaanNya, manusia mempunyai tanggungjawab sosial untuk dapat saling menolong dan memberdayakan mereka yang butuh topangan sehingga dapat kembali mengangkat martabatnya ditengah-tengah kehidupan masyarakat. Salib Putih mempunyai tanggungjawab pula untuk menjalankan fungsinya ditengah-tengah masyarakat dengan mengambil peran sebagai lembaga sosial kemasyarakatan untuk mengangkat martabat manusia yang "kehilangan" martabatnya.

Salib Putih adalah wujud nyata tanggungjawab pelayanan kepada Tuhan yang telah memberikan kasih dan keselamatan melalui pengorbanannya dan tanggungjawab kita kepada sesama yang menderita dimana segala bentuk pelayanan yang ada didasarkan ketulusan dan kesucian hati.

Visi dari Panti Yayasan Salib Putih adalah mewujudkan kasih Allah kepada manusia demi keselamatan manusia secara utuh. Sementara Misinya adalah memberikan pelayanan kepada orang-orang terlantar dengan cara memberikan perawatan, pendidikan serta pendampingan, agar menjadi manusia bermartabat yang hidup secara utuh, layak dan penuh pengharapan. 
Dari visi dan misi tersebut, maka Yayasan Sosial Kristen Salib Putih menyelenggarakan kegiatan dan program layanan sosial dalam bentuk Panti Asuhan untuk anak-anak terlantar, Panti Karya untuk orang-orang usia produktif terlantar, Panti Wredha untuk orang-orang usia lanjut terlantar serta Balai Pengobatan untuk pelayanan kesehatan masyarakat.

Saat ini, Panti Karya Salib Putih menampung warga usia produktif (25-60) yang tidak mampu bekerja di organisasi atau lembaga yang kompetitif. Hal ini terjadi karena warga yang terganggu jiwanya namun dalam usia produktif, panti ini mau menerima dengan diberi penampungan sederhana, pemberian uang lauk pauk sederhana dengan pembimbingan untuk bekerja di kebun Kopi.

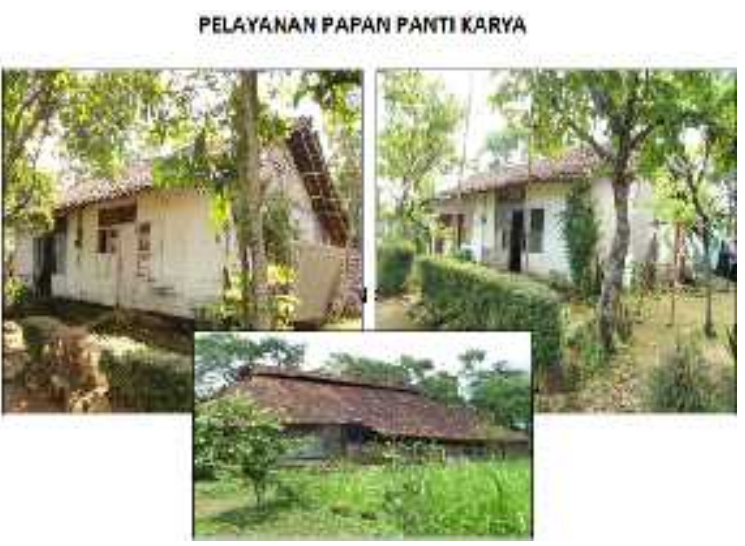

Gambar 3. Pelayanan Papan Panti Karya Salib Putih

Di Panti Karya Salib Putih terdapat 12 Kepala Keluarga yang tinggal menjadi kalayan (klien, warga binaan) bersama dengan keluarganya. Untuk memenuhi kebutuhan mereka, pengelola mengusahakan kopi, mulai dari produksi sampai pennjualan bubuk kopinya. Untuk memenuhi kebutuhan sehari-hari mereka, para kalayan diminta untuk mengolah kebun kopi yang dimiliki oleh Panti Karya Salib Putih seluas 4 Ha.

Kopi diproduksi dan dipanen-ditebaskan. Hasil produksi kopi saat ini adalah 482.75 $\mathrm{kg}$ per ha atau secara total adalah $1971 \mathrm{~kg}$ pertahun. Menurut Manalu (2019), seharusnya produksi kopi di Indonesia mencapai 3 ton per kuintal. Sehingga produktivitas kopi di Panti Karya Salib Putih ini masih sangat terbatas yaitu hanya 16.1 dari produktivitas normal.
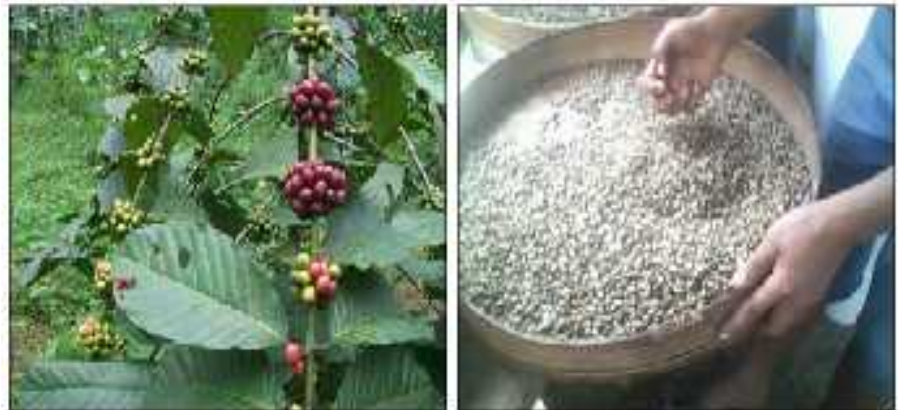

Gambar 4. Pohon Kopi dan Hasil Tanaman Kopi 


\section{Published December 2019}

EKONOMIKAWAN : Jurnal IImu Ekonomi dan Studi Pembangunan

ISSN : 1693-7600 (Print), ISSN : 2598-0157 (Online), http://jurnal.umsu.ac.id/indexphp/ekawan

Untuk mencapai tujuan peningkatan kapasitas hasil produksi kopi, dilakukan dengan mereview kondisi eksisteng dari tanah. Tahap awal adalah dengan melakukan analisis tanah. Analisis tanah dilakukan untuk mengevaluasi kesuburan dari tanah serta sifat-sifat lainnya. Analisis tanah dilakukan dengan pengambilan contoh tanah yang merupakan suatu fase yang paling penting sebab pengambilan contoh tanah yang akurat dapat menghasilkan analisis yang sesuai dengan kondisi sebenarnya.

Contoh tanah wajib memperhatikan perbedaan-perbedaan topografi, sifat atau watak tanah, warna tanah dan perbedaan-perbedaan lain yang dapat menjamin keakuratan hasil analisis. Contoh tanah harus berasal dari tanah yang homogen namun merata di seluruh bidang sehingga diperoleh perwakilan yang baik. Selain itu, pengambilan contoh tanah juga harus dilakukan di tempat yang permukaannya bersih, dan terbebas dari daun, sisa tanaman dan kotoran.

Berdasarkan hasil analisis tanah dari pengujian laboratorium, maka dilakukan pemilihan teknik pemupukan yang tepat. Pemberian pupuk mutlak dilakukan pembudidayaan suatu tanaman. Pupuk menyediakan sumber organik dan anorganik untuk meningkatkan pertumbuhannya tanaman. Manfaat pemupukan adalah :

1. Perbaikan kondisi tanaman melalui pemupukan secara optimal dan teratur dengan demikian, tanaman memiliki daya tahan baik dan tidak mudah terkena hama penyakit.

2. Peningkatan produktivitas dan mutu. Pemupukan pada tahun awal berfungsi untuk merangsang pertumbuhan vegetatif. Pada tanaman kopi, pemupukan bermanfaat untuk memperbesar biji kopi serta meningkatkan mutu, menghasilkan rendaman atau uitivering yang tinggi sehingga biaya pemetikan menjadi murah.

3. Tanaman kopi bersifat biennial bearing yaitu fluktuatifnya hasil panen. Pada suatu periode akan memiliki hasil panen yang tinggi namun periode yang lain akan menghasilkan panen rendah. Pada periode dimana hasil panen rendah akan menurun $40 \%$ dibandingkan dengan saat panen tinggi.

Pemupukan secara optimal dapat menjaga stabilisasi hasil produksi karena penurunan hasil panen tidak terlalu banyak yaitu hanya sebesar 20\%. Pemupukan dilakukan melalui parit yang dibuat melingkari pohon dengan kedalaman lebih kurang 10 $\mathrm{cm}$. Jarak antara satu parit dangan parit lainnya lebih kurang 1 meter . Cara lain yang dapat dilakukan adalah melubangi pada piringan sekitar pangkal batang yang kemudian ditentukan titik - titik/ lubang yang berguna sebagai tempat pupuk. Titik ini harus searah dengan empat penjuru mata angin.

Selain pemberian pupuk, juga diberikan zat perangsang tumbuh. Zat Pengatur Tumbuh (ZPT) memiliki peran yang cukup vital bagi pertumbuhan tanaman terutama tanaman kopi. Zat Pengatur Tumbuh terdiri dari senyawa organik yang bukan hara. ZPT berfungsi untuk memacu, menghambat dan dapat merubah proses fisiologi dari tumbuhan.

Selain memperbaiki kualitas tanah, juga dilakukan perbaikan kualitas dan kuantitas tanaman kopi supaya mencapai hasil yang maksimal. Berdasarkan hasil pengamatan, sebagian tanaman kopi merupakan tanaman tua, oleh sebab itu perlu dilakukan peremajaan tanaman kopi. Tanaman kopi yang sudah tua menjadi tidak produktif lagi. Selain itu, tanaman kopi yang sudah tua akan rentan dengan serangan hama dan penyakit. Oleh sebab itu, tanaman kopi yang sudah tua akan memiliki tingkat produktivitas yang rendah sekali.

Selain itu juga dapat dilakukan dengan memilih varietas unggulan dari tanaman kopi. Bibit kopi dengan varietas unggulan telah terbukti memiliki produktivitas yang lebih tinggi. 
Pada kegiatan pengabdian masyarakat di Panti Karya Salib Putih ini dilakukan penanaman 250 pohon baru. Penanaman pohon baru ini diharapkan dapat meningkatkan produktivitas dari tanaman kopi.

Selain dengan penanaman pohonbaru, peremajaan tanaman kopi dilakukan dengan melakukan pemangkasan. Pemangkasan secara berkala yang dilakukan dengan memangkas bagian-bagian tanaman yang tidak berguna. Diantaranya adalah cabang yang sudah tua, ranting yang mengering, atau daun yang terlalu rimbun. Pemangkasan bermanfaat bagi peningkatan produktivitas tanaman kopi. Dengan dilakukannya pemangkasan diharapkan dapat memacu pertumbuhan bunga dan buah. Dengan demikian, tanaman kopi bisa panen tiap bulan, produksi meningkat, mutu lebih baik, umur produktif lebih lama serta pemeliharaan lebih mudah.

Tujuan dari pemangkasan adalah (a) untuk memperoleh cabang baru (b) memudahkan memperoleh sinar matahari yang akan merangsang pembentukan bunga (c) membuang cabang tua yang tidak produktif (d) memperbaiki peredaran udara guna merangsang penyerbukan bunga (e) membuang cabang yang terserang hama/penyakit.

Pada tujuan pengabdian masyarakat kedua dan ketiga, yaitu meningkatkan manajemen pengolahan kopi menjadi produk kopi dan meningkatkan jumlah hasil produk kopi. Panti Karya Salib Putih mengalami kendala keterbatasan sarana pengelolaan kopi. Saat ini peralatan yang digunakan adalah mesin roasting yang masih sederhana yaitu mesin roastng yang belum memiliki alat pengatur suhu.

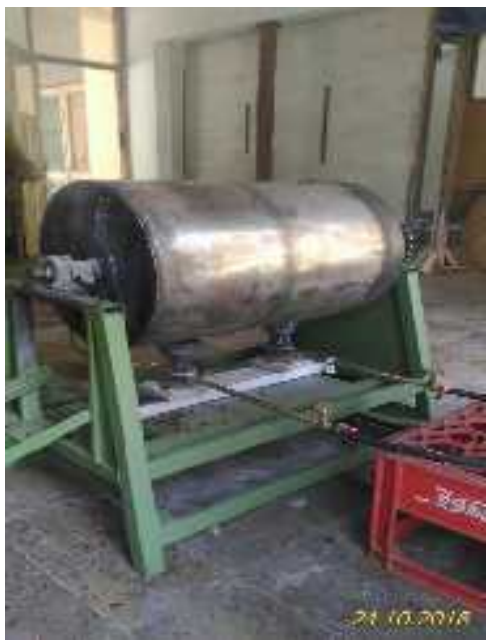

Gambar 5. Mesin Roasting Saat Ini

Mesin roasting inipun adalah mesin pinjaman dari PT. Rumekso Mekaring Sabda sehingga tidak bisa kapanpun menggunakan, dan kapanpun PT Rumekso membutuhkan harus dikembalikan. Karena alat roasting belum memiliki pengatur suhu maka seringkali bubuk kopi hasilnya tidak memenuhi kualitas, kuantitas dan kontinuitas yang diharapkan. Oleh sebab itu, untuk menghasilkan hasil produk kopi dengan hasil yang baik, dibutuhkan alat roasting yang baik, yaitu mesin roasting yang memiliki pengatur suhu. 


\section{Published December 2019}

EKONOMIKAWAN : Jumal IImu Ekonomi dan Studi Pembangunan

ISSN : $1693-7600$ (Print), ISSN : 2598-0157 (Online), http://jurnal.umsu.ac.id/indexphplekawan

Mesin roasting kopi yang baru ini memiliki kapasitas $25 \mathrm{Kg}$ dan berfungsi untuk menyangrai kopi, dengan sistem kerja berputar. Mesin yang baru ini memiliki alat pengatur suhu sehingga panas lebih merata dan kualitas kopi menjadi lebih baik. Diharapkan dengan adanya mesin yang baru ini dapat meningkatkan kualitas dari hasil produk kopi yang dihasilkan oleh Panti Karya Salib Putih.

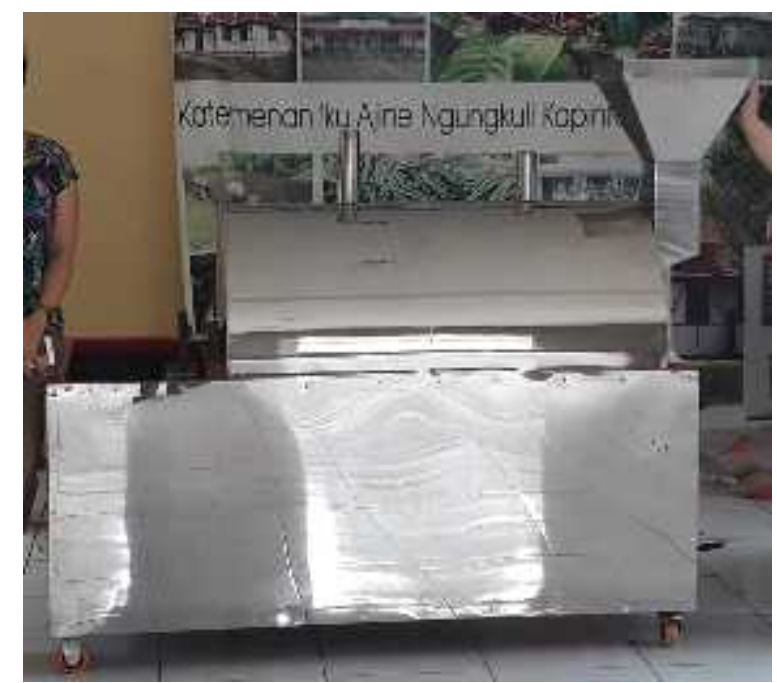

Gambar 6. Mesin Roasting Baru

Masalah lain yang dihadapi oleh Pati Karya Salib Putih dalam kaitannya dengan pengolahan kopi adalah masalah penjualan. Saat ini, kopi bubuk diolah, kemudian dikemas dan dijual secara door to door. Tenaga kalayan sudah diatas 45 tahun dan tidak produktif seperti SDM lainnya. Hal ini menyebabkan hasil penjualan dari bubuk kopi juga tidak maksimal. Padahal berjarak kurang dari 500 meter dari Panti Karya Salib Putih terdapat ada wisata Agro Salatiga yang ramai dikunjungi wisatawan dan hotel D'Emmerick yang sejuk, nyaman dan indah, yang mampu menjadi mitra usaha dari panti karya ini. Disamping itu, jika sudah memenuhi syarat, panti bisa mengusahakan warung kopi dimana pelanggan utamanya adalah penyuka kopi yang datang ke agrowisata, hotel atau meeting atau sekedar kongkow kongkow belaka, dimana lokasi usaha hanya berjarang sekitar $5 \mathrm{~km}$ dari pusat kota, pendidikan tinggi UKSW dan IAIN Salatiga dengan puluhan ribu mahasiswanya.

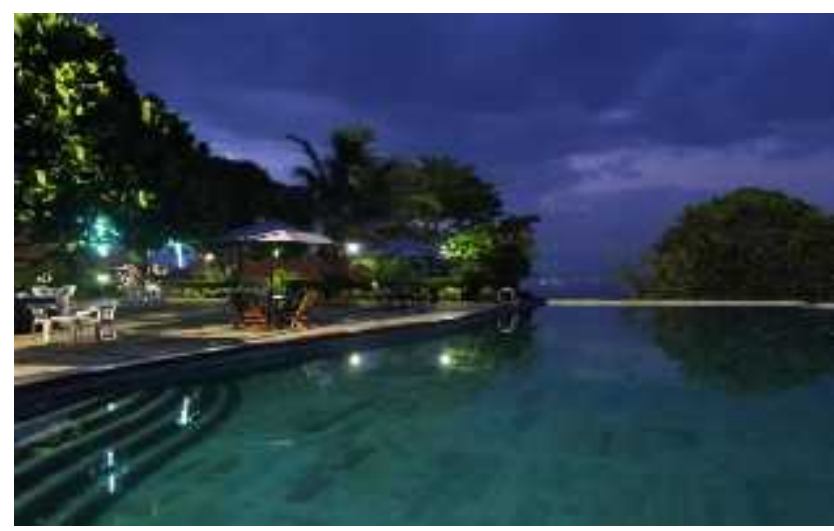

Gambar 7. Suasana D'Emmerick Hotel dan Wisata Agro 
Dengan adanya perbaikan dari pengolahan produk kopi maka Panti Karya Salib Putih bisa melakukan kerjasama dengan D'Emmerick Hotel dan agrowisata sebagai supplier produk kopi. Dengan demikian terdapat kesinambungan hasil penjualan kopi dari Panti Karya Salib Putih.

\section{SIMPULAN}

Tujuan dari kegiatan pengabdian kepada masyarakat ini adalah meningkatkan kapasitas hasil produksi kopi, meningkatkan manajemen pengolahan kopi menjadi produk kopi dan meningkatkan jumlah hasil produk kopi. Peningkatan kapasitas hasil produksi kopi, dilakukan dengan mereview kondisi eksisting dari tanah. Berdasarkan hasil analisis tanah dari pengujian laboratorium, maka dilakukan pemilihan teknik pemupukan yang tepat. Selain memperbaiki kualitas tanah, juga dilakukan perbaikan kualitas dan kuantitas tanaman kopi supaya mencapai hasil yang maksimal dengan melakukan peremajaan tanaman kopi.

Untuk meningkatkan manajemen pengolahan kopi menjadi produk kopi dan meningkatkan jumlah hasil produk kopi, dilakukan dengan pengadaan alat roasting yang baik dan pemasaran hasil produk kopi yang baik pula. Harapan dari seluruh pengabdian masyarakat yang dilakukan adalah terjadinya peningkatan nilai usaha yang dimulai dengan peningkatan nilai usaha dari pertanian kopi dan juga peningkatan nilai usaha dari produk pupuk.

Namun demikian upaya peningkatan nilai usaha yang dilakukan dalam pengabdian masyarakat ini tidak serta merta langsung menunjukkan hasil yang diinginkan.Dibutuhkan waktu dan evaluasi yang komprehensif untuk mewujudkannya

\section{DAFTAR PUSTAKA}

Ari (2014) Program Panti Sosial Bina Karya Yogyakarta, http://masjepret.blogspot.com/2014/02/program-panti-sosial-bina-karya-psbk.html

Herjanto, E. 2007. Manajemen Operasi. Jakarta: Grasindo

Manalu,Juli Etha (2019), Produktivitas Kebun Kopi Indonesia Masih Rendah, Ekonomi Bisnis, https://ekonomi.bisnis.com/read/20190312/99/898582/produktivitas-kebunkopi-indonesia-masih-rendah

Marwasta(2017) Pendampingan Masyarakat Desa Parangtritis dalam Pengelolaan Kawasan Gumuk Pasir Melalui Kegiatan Diversifikasi Usaha Berbasis Sumberdaya Pesisir, Indonesian Journal of Community Engagement, 2 (2), 133-145

Peraturan Menteri Sosial Republik Indonesia (2009) Nomor 106/HUK/2009 tentang Organisasi dan Tata Kerja Panti Sosial di Lingkungan Departemen Sosial

Prasetyo, Budi (2012), Jumlah Gepeng di Jawa Tengah Terbanyak di Indonesia, Tribun news,https://www.tribunnews.com/regional/2012/12/28/jumlah-gepeng-di-jawatengah-terbanyak-di-indonesia. 